DOI: https://doi.org/10.32839/2304-5809/2021-5-93-32

УДК 622.817(571.17)

Крупка Я.А.

Одеський науково-дослідний інститут судових експертиз

Зав'ялова О.Л.

Донецький національний технічний університет

Костенко T.B.

Черкаський інститут пожежної безпеки імені Героїв Чорнобиля

Національного університету цивільного захисту України

\title{
ЛІКВІДАЦІЯ НАСЛІДКІВ ВИБУХІВ МЕТАНОПИЛОПОВІТРЯНИХ СУМІШЕЙ, УСКЛАДНЕНИХ ПОЖЕЖАМИ
}

\begin{abstract}
Анотація. Метою статті є вдосконалення тактики ліквідацї наслідків вибухів газопилових сумішей, ускладнених екзогенними пожежами, в гірничих виробках вугільних шахт, що дозволить своєчасно і в повній мірі забезпечити порятунок застряглих людей, підвищити безпеку роботи гірничих рятувальників при ліквідації наслідків цих аварій, зменшити економічні збитки підприемств. Наукова новизна роботи полягає у розв'язанні науково-прикладної задачі вдосконалення тактики (технології) ліквідації наслідків вибухів газопилових сумішей, ускладнених екзогенними пожежами, в гірничих виробках вугільних шахт, що дозволить своєчасно і в повній мірі забезпечити порятунок застряглих людей, підвищити безпеку роботи гірничих рятувальників при ліквідації наслідків цих аварій, зменшити економічні збитки підприемств, які пов'язані із втратою техніки, гірничих виробок і запасів вугілля, що підготовлені до виїмки, в виїмкових полях, що інтенсивно відпрацьовуються, великих аварійних збитків, які пов'язані із простоями лав або несвоєчасною підготовкою фронту очисних робіт.
\end{abstract}

Ключові слова: аварія, вибух; газопилова суміш, гірничі рятувальники, пожежа, вугільна шахта.

\section{Krupka Yaroslav \\ Odessa Research Institute of Forensic Examinations Zavialova Olena \\ Donetsk National Technical University}

Kostenko Tetiana

Cherkasy Institute of Fire Safety named after Chornobyl Heroes of National University of Civil Defense of Ukraine

\section{ELIMINATION OF THE CONSEQUENCES OF EXPLOSIONS OF METHANO-DUST AIR MIXTURES COMPLICATED BY FIRE}

Summary. The purpose of the article is to improve the tactics of liquidation of explosions of gas-dust mixtures complicated by exogenous fires in the mine workings of coal mines, which will allow timely and full rescue of trapped people, increase safety of rescuers in the aftermath of these accidents, reduce economic costs. During the research, to solve the tasks, the complex used general and special methods, in particular: methods of induction (at the stage of collecting, systematizing and processing information for research) and deduction (in the process of theoretical understanding of the problem), system-analytical , comparative analyzes, method of analysis of definitions, etc. The practical significance of the obtained results is to create new ways to localize and eliminate the consequences of explosions of gas-dust mixtures complicated by exogenous fires in the mine workings of coal mines, which will timely and fully ensure the rescue of trapped people, increase safety of rescue workers. reduce economic losses of enterprises. The scientific novelty of the work is to solve the scientific and applied problem of improving tactics (technology) to eliminate the consequences of explosions of gas-dust mixtures complicated by exogenous fires in the mine workings of coal mines, which will timely and fully ensure the rescue of trapped people. in the aftermath of these accidents, reduce the economic losses of enterprises associated with the loss of equipment, mine workings and coal reserves prepared for excavation, in the excavation fields, intensively worked out, large emergency losses associated with lava downtime or untimely preparation of the front of treatment works. It is established that in the elimination of the consequences of explosions of gas-dust mixtures complicated by exogenous fires in the mine workings of coal mines, safe and efficient localization of fire, as well as cooling of fire gases can be carried out by creating a "explosion" of collapsed rocks emergency production. The dynamics of cooling of fire gases in the "rock" plug is described by a mathematical model of the process of movement of heated air in a porous medium in two-dimensional and one-dimensional formulation. Improving tactics to eliminate the consequences of explosions of gas-dust mixtures complicated by exogenous fires in the mine workings of coal mines will allow timely and full rescue of trapped people, increase the safety of rescuers in the aftermath of these accidents, reduce economic losses. machines, mechanisms, equipment, mine workings and coal reserves prepared for excavation, in excavation fields that are intensively worked out, large emergency losses associated with lava downtime or untimely preparation of the front of treatment works. To numerically solve the obtained system of differential equations and determine the parameters of the zone of the rock plug in the products it is necessary to continue the experimental study of the porosity of the plug material, as well as to develop an algorithm and PC calculation program for these parameters.

Keywords: accident, explosion; gas-dust mixture, mountain rescuers, fire, coal mine. 
$\Pi^{\circ}$ остановка проблеми. На вугільних шахтах проводять роботи підвищеної небезпеки (вибухонебезпечні, пожежно-небезпечні, небезпечні за обваленнями виробок та гірничих порід, раптовими проривами рудникових газів, вугілля, порід, води тощо). Ці роботи проходять в умовах непередбаченості, раптової зміни гірничо-геологічних умов або природних сил, при недотриманні вимог нормативно-правових актів 3 охорони праці з боку персоналу підприемств та можуть спричинити тяжкі наслідки, які супроводжуються численними жертвами та матеріальними збитками. 3 переходом гірничих робіт вугільних шахт на глибокі горизонти зростає негативний вплив підвищених гірничого тиску, температури вміщаючих порід, газорясності та інших фракторів [1].

Одними 3 найбільш небезпечних видів аварій $\epsilon$ вибухи газопилових сумішей (далі - вибухи) в гірничих виробках вугільних шахт. При вибухах в підземних умовах вугільних шахт виникають такі вражаючі фрактори: фрронт повітряної ударної хвилі (рухома по гірничій виробці зона миттевої зміни (збільшення) тиску, щільності і температури середовища); високотемпературний фрронт полум'я (рухома по гірничій виробці зона хімічної реакції і нагрітих газів); отруйні та шкідливі продукти горіння $\left(\mathrm{CO}, \mathrm{CO}_{2}, \mathrm{CH}_{4}, \mathrm{~N}_{2}\right.$, $\mathrm{H}_{2} \mathrm{~S}$ тощо), недостатня кількість кисню у повітрі робочої зони, що призводить до численних людських жертв, значних матеріальних збитків для підприемств. Найбільш небезпечними є вибухи, ускладнені екзогенними пожежами. При ліквідації цих пожеж є загроза повторних вибухів, обрушення кріплення гірничих виробок. Тому перед вченими стоїть задача вдосконалення тактики ліквідації наслідків вибухів, ускладнених пожежами, в гірничих виробках вугільних шахт, що дозволить своєчасно і в повній мірі підвищити безпеку гірничих рятувальників при ліквідації наслідків цих аварій, зменшити економічні збитки підприємств [2;3].

Аналіз останніх досліджень і публікацій. Фундаментальні дослідження в галузі фрізики і механіки вибуху представлені в роботах Баракова А. А., Ландау Л. Д., Зельдовича Я. Б., Христиановича С. А., Садовського М. А. та ін. та послужили основою створення теорії формування, поширення і локалізації вибухів метанопилоповітряних сумішей у вугільних шахтах. Істотний внесок у розвиток ціеї теорії, встановлення умов утворення вибухонебезпечного середовища, а також створення способів і технічних засобів ведення гірничорятувальних робіт внесли Балтайтис В. Я., Бусигін К. К., Бобров А. І., Грядущий Б. А., Доценко В. Ф., Зрелий М. Д., Макаренко В. Л., Маркович Ю. М., Скочинський А. А., Соболев Г. Г., Чарков В. П., Чеховських О. М. та ін. Подальший розвиток питання вибухопридушення та ліквідації пожеж у вугільних шахтах отримали у роботах Болбата I. Ю., Грекова С. П., Гусара Г. А., Зінченко І. М., Кудінова Ю. В., Морева О. М., Осипова С. М. та ін. [4].

Виділення невирішених раніше частин загальної проблеми. Основними причинами розвитку і ускладнень вибухів є порушення кріплення та обвалення порід у рудничних виробках, порушення вентиляційних споруд і режи- му провітрювання аварійних ділянок, повторні вибухи, виникнення екзогенних пожеж, захаращення виробок машинами та механізмами, устаткуванням, елементами кріплення, породою тощо. Але питаннями дослідження цих явищ, розвитку тактики ліквідації наслідків вибухів газопилових сумішей, ускладнених екзогенними пожежами, в гірничих виробках вугільних шахт, в останні роки, практично вчені не займалися. Тому дані знання потребують оновлення.

Формулювання цілей статті. Мета статті вдосконалення тактики ліквідації наслідків вибухів газопилових сумішей, ускладнених екзогенними пожежами, в гірничих виробках вугільних шахт, що дозволить своєчасно і в повній мірі забезпечити порятунок застряглих людей, підвищити безпеку роботи гірничих рятувальників при ліквідації наслідків цих аварій, зменшити економічні збитки підприемств.

Методологічною основою досліджень роботи $€$ загальні закони та категорії теорії пізнання, зокрема, положення матеріалістичної діалектики, які сприяли розумінню об’єкта, предмета, мети i завдань дослідження у контексті взаємообумовленості здобутків і потреб практики. Методи формальної логіки (аналіз, синтез, дедукція, індукція, аналогія, абстрагування) надали змогу детальніше усвідомити зміст досліджуваних питань роботи. Під час проведення досліджень, для розв'язання поставлених задач, в комплексі застосовувалися загальнонаукові та спеціальні методи, зокрема: методи індукції (на етапі збору, систематизації і обробки інформації для проведення досліджень) та дедукції (у процесі теоретичного осмислення проблеми), системно-аналітичний, порівняльний аналізи, метод аналізу визначень тощо.

Виклад основного матеріалу дослідження. Ліквідації наслідків вибухів газопилових сумішей, ускладнених екзогенними пожежами, в гірничих виробках вугільних шахт, пов'язана 3 небезпекою для гірничих рятувальників, великими трудовитратами гірничорятувальних частин та економічними збитками для підприемств.

Для локалізації екзогенних пожеж на вихідному струмені повітря, як правило, використовується завіса 3 водорозпушенням. Нами пропонується принципово нове рішення. На шляху руху пожежі пропонуеться утворювати породну пробку методом вибухового обрушення дезінтегрованого гірничого масиву.

При відпрацюванні пологих пластів з керуванням покрівлі повною руйнаціею, замість ізолюючих перемичок, що локалізують пожежу у виробленому просторі, можна використовувати обрушені породи [5]. Вирішивши завдання фрільтрації і теплопередачі підземних газів [6], можна визначити необхідний обсяг зруйнованих пород і максимальні розміри шматків, які забезпечують найбільш інтенсивне охолодження пожежних газів. Розроблено розрахункові методи прогнозування дроблення пород вибухівкою і визначення макси-

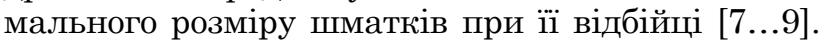
Встановлена фрункціональна залежність між гранулометричним складом підірваного матеріалу і відстанню між свердловинами та їх діаметром.

Домогтися створення породної пробки можна й іншим шляхом - руйнуванням кріплення 
гірничої виробки. Після установки на вузлах аркового кріплення накладних зарядів з кумулятивним ефектом досягається їх руйнування. Кількість секцій, що підлягають руйнуванню, визначається розрахунками, виходячи 3 необхідного обсягу зруйнованої породи.

Математична модель придушення негативних фракторів, що виникають при пожежах, повинна відповісти на питання:

які повинні бути розміри області в породах покрівлі виробки, в яку закладається вибухівка, щоб шматки зруйнованого масиву заповнили нижчерозташований обсяг виробки і саму порушену область?

яка повинна бути довжина штучно створеної у виробці пористого середовища, щоб знизити до безпечних значень величину швидкості руху повітря у виробках та його температуру?

3 огляду на симетричність конфігурації перпендикулярного перетину підземних виробок щодо площини ZOX (рис. 1) фрізичні параметри завдання усереднюються по ширині виробки.

На рис. 1 заштрихований перетин А в площині області, яку підривають, відповідної перетину ОВСД, яке повинно бути заповнене пористим середовищем. Для џого необхідно виконання умови:

$$
m=\frac{h_{1}}{h_{1}+h_{2}}
$$

де $m$ - пористість обрушеного штучного масиву; $\mathrm{h}_{1}$ - висота виробки, м; $\mathrm{h}_{2}$ - висота об'єкта, який обрушується, в покрівлі виробки, м.

Пористість $m$ обрушеного штучного масиву залежить від міцності порід, розташування шпурів і кількості вибухівки в кожному з них.
Цей параметр, як і середній розмір шматків породи, необхідно визначити в експериментальних дослідженнях. Висоту об'єкта, який обрушуеться, в покрівлі виробки знаходимо, використовуючи формулу (2):

$$
h_{2}=\frac{h_{1}(1-m)}{m} \text {. }
$$

Обчислення цього параметра безпосередньо залежить від результатів експериментів по визначенню пористості $m$.

Другий з визначених в даних дослідженнях параметрів - це довжина штучно створеної у виробці пористого середовища. Вона відповідає довжині сторони ВC заштрихованої області А (рис. 1) і позначена через $a$.

Розрахунок величини $a$ пов'язаний $з$ визначенням динаміки швидкості фрільтрації повітря і його температури в пористому середовищі. Нагріте під час пожежі повітря на великій швидкості проникає в пористе середовище. При цьому величина $a$ вибирається такою, щоб на виході 3 пористого середовища температура і швидкість повітря мала бути безпечною для людей по ходу вентиляційного струменю, або значення швидкості повітря і його температури на виході 3 пористого середовища не могли сприяти рецидиву пожежі, повторного вибуху газопилової суміші на аварійній дільниці.

Розглянемо дослідження процесу руху нагрітого повітря в пористому середовищі. Щоб вивчити рух у виробці нагрітого при пожежі повітря, необхідно для області АВСД (рис. 2) скласти рівняння фрільтрації повітря, стану, нерозривності

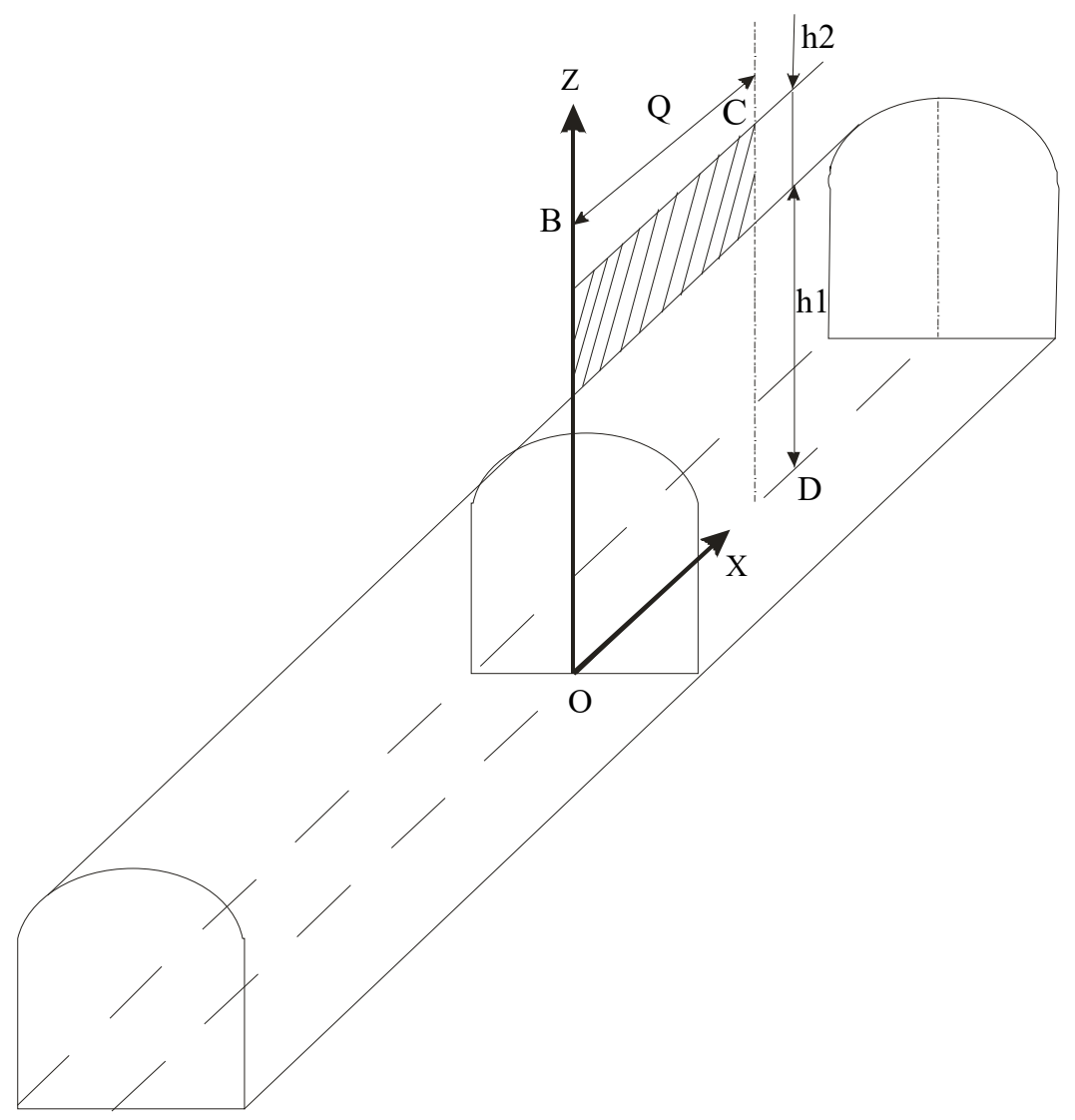

Рис. 1. Вибір системи координат для вирішення завдання руху нагрітого рудничного повітря через штучне пористе середовище 


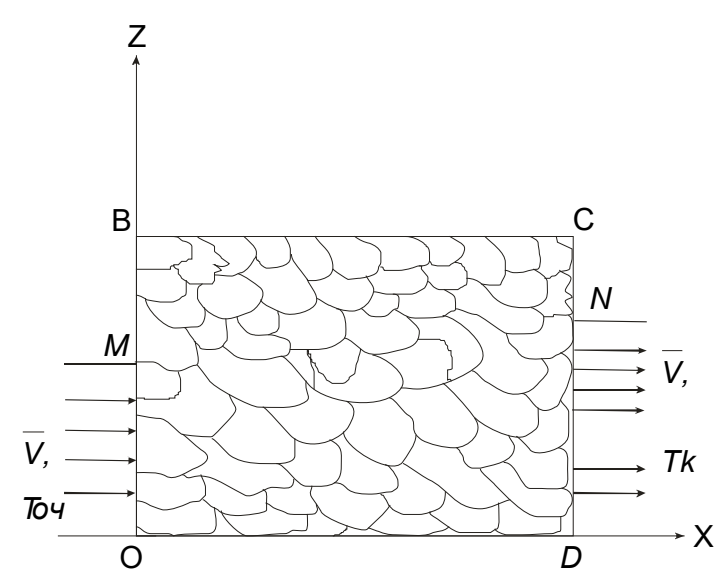

Рис. 2. Схема пористого середовища, штучно створенного в гірничій виробці

та енергії. Спільне рішення цих рівнянь дозволить визначити такі параметри, як швидкість руху повітря, його тиск, щільність і температуру. При високих температурах повітря на вході в пористе середовище і швидкому прогріванні пористого середовища необхідно в систему рівнянь ввести рівняння для визначення зміни температури шматків породи, обрушеної під час вибуху. Однак попередні дослідження [10] показали, що пористе середовище дуже інертне по відношенню до прогріву шматків породи гарячим повітрям, i таке рівняння вводити не потрібно.

Спочатку вищевказані рівняння випишемо для двовимірної області ОВСД (рис. 2). Якщо в контрольних розрахунках параметрів цієї математичної моделі виявиться, що величина $\mathrm{BC}=a$ набагато більше висоти виробки $\mathrm{OB}=\mathrm{h}_{2}$, то систему диференціальних рівнянь можна істотно спростити, переходячи до одновимірної моделі.

У двовимірній постановці система диференщіальних рівнянь, що описує рух нагрітого повітря в обрушених у виробці штучним вибухом породах, має такий вигляд:

$$
\left\{\begin{array}{l}
\frac{\partial V x}{\partial t}=-\frac{1}{\rho} \frac{\partial P}{\partial x}-\frac{g V x}{K_{\phi}} ; \\
\frac{\partial V z}{\partial t}=-\frac{1}{\rho} \frac{\partial P}{\partial z}-\frac{g V z}{K_{a}}-g ; \\
m \frac{\partial \rho}{\partial t}+\frac{\partial(V x \rho)}{\partial x}+\frac{\partial(V z \rho)}{\partial z}=0 ; \\
\rho=\frac{P}{R T} ; \\
\rho_{n} C_{n} \frac{\partial T}{\partial t}=\lambda \operatorname{divgrad} T-\rho C_{P} \operatorname{div}(T \bar{V})-\frac{K \tau}{h_{1}+h_{2}}\left(T-T_{n}\right),
\end{array}\right.
$$

де $\mathrm{V}_{\mathrm{x}}, \mathrm{V}_{\mathrm{z}}$ - складові швидкості фрільтращії повітря, м/c; x, z - просторові координати (рис. 1, 2), м;

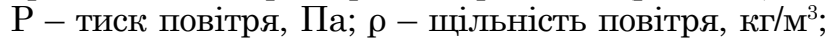
$\mathrm{g}$ - прискорення вільного падіння, м/ $\mathrm{c}^{2} ; \mathrm{K}_{\mathrm{\phi}}$ - коефіціент фрільтращіі, м/с; Т - температура повітря, К;

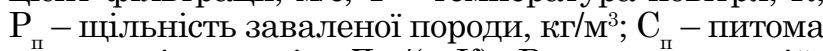
теплоемність порід, Дж/(кгК); $\mathrm{R}$ - газова постійна, Дж/(кгК); $\lambda$ - коефріцієнт теплопровідності, Вт/ (мК); $\mathrm{Cp}$ - питома теплоємність повітря, Дж/(кгК); t - час, с; $\bar{V}$ - вектор швидкості повітря, м/с; $\mathrm{K}_{\tau}-$ коедіціент нестаціонарного теплообміну порід 3 фільтруємим повітрям, Дж ( $\left.\mathrm{s}^{2} \mathrm{cK}\right) ; \mathrm{T}_{\text {п }}$ - температура шматків породи пористого середовища, $\mathrm{K}$.
Система диференщіальних рівнянь (3) настільки складна, що отримати аналітичне piшення ціеї системи практично неможливо. Тому для отримання чисельного рішення систему рівнянь (3) необхідно перевести в кінцево-різницеву схему, отримати алгоритм розрахунку фрункцій $\mathrm{V}_{\mathrm{x}}, \mathrm{V}_{\mathrm{y}}, \rho, \mathrm{P}$ та $\mathrm{T}$ і скласти програму розрахунку на EOM даних параметрів за вказаним алгоритмом.

Система диференціальних рівнянь (3) складена на підставі досліджень процесів руху повітря в пористих середовищах, наведених в роботах [11...13]. Обумовлені в системі рівнянь параметри $\mathrm{V}_{\mathrm{y}}, \mathrm{V}, \rho, \mathrm{P}$ та T $е$ фоннкціями часу і просторових координат. Для спрощення викладок аргументи в написанні фрункцій не виписані.

Для замикання системи диференщіальних рівнянь (3) їі необхідно доповнити граничними по контуру AMBCND i початковими умовами. При цьому потрібно виходити з умови такої фрізичної моделі, в якій контур MBCN і OD непроникні. Позначимо його через $\mathrm{G}_{1}$. Відрізки $\mathrm{OM}$ i $\mathrm{ND}$ - проникні. Позначимо їх відповідно $\mathrm{G}_{2} \mathrm{i} \mathrm{G}_{3}$.

Відповідно до введених обмежень на властивості контуру OMBCND, граничні і початкові умови мають такий вигляд:

$$
\left\{\begin{array}{l}
\left.V_{x}\right|_{G 2}=V_{0} ;\left.V_{z}\right|_{G_{2}}=0 ;\left.T\right|_{G 2}=T_{o 4} ;\left.P\right|_{G 2}=P_{h} ; \\
\left.\rho\right|_{G 2}=\rho_{n} \mid ; \\
\left.\frac{\partial V x}{\partial n}\right|_{G 1}=\left.\frac{\partial V z}{\partial n}\right|_{G 1}=0 ;\left.T\right|_{G 1}=T_{n} ;\left.\frac{\partial P}{\partial n}\right|_{G 1}=0 \\
\left.\rho\right|_{G 1}=\left.\frac{P}{R T}\right|_{G 1} ; \\
\left.V_{x}\right|_{G 1}=V_{1} ;\left.V_{z}\right|_{G 3}=0 ;\left.T\right|_{G 3}=T_{k} ;\left.P\right|_{G \#}=P_{\text {нор. }}+\alpha ; \\
\left.\rho\right|_{G 3}=\left.\frac{P}{R T}\right|_{G 3} \cdot \\
\left.\mathrm{B} \mathrm{області} \mathrm{OMBCD} V_{X}\right|_{t=0}=\left.V_{Z}\right|_{t=0}=0 ;\left.P\right|_{t=0}=P_{\text {нори }} ;\left.T\right|_{t=0}=T_{n},
\end{array}\right.
$$
де $\mathrm{V}_{0}$ - швидкість руху нагрітого повітря, м/с; $\mathrm{T}_{\text {оч }}$ - температура нагрітого при пожежі в виробці повітря, $\mathrm{K} ; \mathrm{P}_{\text {н }}$ - тиск фрронту нагрітого повітря, Па; $\rho_{\text {н }}$ - щільність нагрітого повітря перед заслоном у вигляді пористого середовища, Па; $\mathrm{n}$ - нормаль до контуру $\mathrm{G}_{1} ; \mathrm{V}_{1}$ - швидкість повітря на виході з пористого середовища, м/c; $\mathrm{T}_{\mathrm{k}}$ - температура повітря на виході 3 пористого середовища, $\mathrm{K} ; \mathrm{P}_{\text {норм }}+\alpha-$ тиск повітря, допустимий Правилами безпеки для шахтних виробок, Па.

Як вже було сказано раніше, при розрахованому значенні можна істотно спростити систему рівнянь (3), перейшовши в цьому випадку до одновимірної моделі. При цьому система диференціальних рівнянь (3) перепишеться в наступному вигляді:

$$
\begin{aligned}
& \frac{\partial V x}{\partial t}=-\frac{1}{\rho} \frac{\partial P}{\partial x}-\frac{g V x}{K_{\Phi}} ; \\
& m \frac{\partial \rho}{\partial t}=-\frac{\partial\left(V_{X} \rho\right)}{\partial x} ; \\
& \rho=\frac{P}{R T} ; \\
& \rho C_{n} \frac{\partial T}{\partial t}=\lambda \frac{\partial^{2} T}{\partial x^{2}}-\rho C_{\rho} \frac{\partial T}{\partial x}-\frac{K_{\tau}}{h_{1}+h_{2}}(T-T n) .
\end{aligned}
$$


Рішення системи рівнянь (5), що отримуеться чисельними методами, відноситься до відрізка OD виробки, заповненої шматками обрушеної при штучному вибуху породи. Система рівнянь (5) замикаеться, якщо їі доповнити початковими умовами на відрізку OD і граничними умовами в точках O i D (лінія по осі OX на рис. 2). Граничні і початкові умови (4) спрощуються і приймають такий вигляд:

$$
\begin{aligned}
& \left.V x\right|_{x=a}=V_{1} ;\left.T\right|_{x=a}=T_{k} ;\left.P\right|_{x=a}=P_{\text {ноорм }}+\alpha ;\left.\rho\right|_{x=a}=\frac{P}{R T} \\
& \left.V x\right|_{x=0}=V_{0} ;\left.T\right|_{x=0}=T_{\text {оч }} ;\left.P\right|_{x=0}=P_{u} ;\left.\rho\right|_{x=o}=\rho_{u} \\
& \text { По відрізку OD } \\
& \left.V x\right|_{t=0}=0 ;\left.T\right|_{t=0}=T_{n} ;\left.P\right|_{t=0}=P_{\text {ноори }} ;\left.\rho\right|_{t=0}=\left.\frac{P}{R T}\right|_{t=0} .
\end{aligned}
$$

Проводячи аналітичні дослідження можливості застосування у вугільних шахтах направленого вибуху для гасіння та локалізації пожеж у виробках, приходимо до наступних висновків:

локалізація пожежі та охолодження пожежних газів можлива шляхом створення пробки обрушенням пород зони непружних деформацій покрівлі виробки;

обрушення пород дезінтегрованого гірничого масиву слід проводити за рахунок руйнування елементів кріплення гірничих виробок;

динаміка охолодження пожежних газів в породній пробці описуеться математичною моделлю процесу руху нагрітого повітря в пористому середовищі в двовимірній і одновимірній постановщі;

для чисельного рішення отриманої системи дифреренщіальних рівнянь і визначення параметрів зони породної пробки у виробках необхідно продовжити експериментальне дослідження пористості матеріалу пробки, а також розробити алгоритм і програму розрахунку на EOM цих параметрів.

Практичне значення отриманих результатів полягає в створенні нових способів локалізації та ліквідації наслідків вибухів газопилових сумішей, ускладнених екзогенними пожежами, в гірничих виробках вугільних шахт, що дозволить своєчасно і в повній мірі забезпечити порятунок застряглих людей, підвищити безпеку роботи гірничих рятувальників при ліквідації наслідків цих аварій, зменшити економічні збитки підприемств.

Наукова новизна роботи полягає у розв'язанні науково-прикладної задачі вдосконалення так- тики (технології) ліквідації наслідків вибухів газопилових сумішей, ускладнених екзогенними пожежами, в гірничих виробках вугільних шахт, що дозволить своєчасно і в повній мірі забезпечити порятунок застряглих людей, підвищити безпеку роботи гірничих рятувальників при ліквідації наслідків цих аварій, зменшити економічні збитки підприемств, які пов'язані із втратою техніки, гірничих виробок і запасів вугілля, що підготовлені до виїмки, у виїмкових полях, що інтенсивно відпрацьовуються, великих аварійних збитків, які пов'язані із простоями лав або несвоєчасною підготовкою фрронту очисних робіт.

Висновки i пропозиції. Встановлено, що при ліквідації наслідків вибухів газопилових сумішей, ускладнених екзогенними пожежами, в гірничих виробках вугільних шахт, безпечну i ефрективну локалізацію пожежі, а також охолодження пожежних газів можна проводити шляхом створення за рахунок енергії направленого вибуху «пробки» з обрушених пород зони непружних деформащій покрівлі аварійної виробки. Динаміка охолодження пожежних газів в «породній» пробці описуеться математичною моделлю процесу руху нагрітого повітря в пористому середовищі в двовимірній і одновимірній постановці.

Вдосконалення тактики ліквідації наслідків вибухів газопилових сумішей, ускладнених екзогенними пожежами, в гірничих виробках вугільних шахт, дозволить своєчасно і в повній мірі забезпечити порятунок застряглих людей, підвищити безпеку роботи гірничих рятувальників при ліквідації наслідків цих аварій, зменшити економічні збитки підприемств, які пов'язані із втратою машин, механізмів, обладнання, гірничих виробок і запасів вугілля, що підготовлені до виїмки, в виїмкових полях, що інтенсивно відпрацьовуються, великих аварійних збитків, які пов'язані із простоями лав або несвоєчасною підготовкою фрронту очисних робіт.

Для чисельного рішення отриманої системи диференціальних рівнянь динаміки охолодження пожежних газів в породній пробці і визначення параметрів зони породної пробки у виробках, необхідно продовжити експериментальне дослідження пористості матеріалів порід пробки, а також розробити алгоритм і програму розрахунку на ЕОМ цих параметрів.

\section{Список літератури:}

1. Долженков А.Ф., Негрей Т.А. Анализ основных направлений создания безопасных условий труда подземных рабочих угольных шахт. Вісті Донецького гірничого інституту : Всеукраїнський науково-технічний журнал. Вип. 1(36)-2(37). Красноармійськ : ДВНЗ «ДонНТУ», 2015. С. 123-129.

2. Santosh Kumar Ray, Niroj Kumar Mohalik, Asfar Mobin Khan, Debashish Mishra, Nikhil Kumar Varma, Jai Krishna Pandey, Pradeep Kumar Singh (2020) CFD modeling to study the effect of particle size on dispersion in 201 explosion chamber: An overview. International Journal of Mining Science and Technology. Volume 30. Issue 3. Рp. 321-327.

3. Зав'ялова О.Л., Костенко В.К. Механізм розвитку вибухів вугільного пилу в мережі гірничих виробок шахт. Геотехнічна механіка : міжвід. зб. наук. праць. ІГТМ ім. М.С. Полякова НАН України. Дніпро, 2017. Вип. 135. С. 52-63.

4. Зав’ялова О.Л., Костенко В.К., Крупка А.А., Дузь Л.Є., Кралюк М.О. Тактика ліквідації наслідків вибухів газопилових сумішей у гірничих виробках вугільних шахт. Науковий вісник ДонНТУ. 2020. № 1(2)-2(3).

5. Левашев А.Л. и др. Локализующие свойства обрушенных пород при пожарах в выработанном пространстве. Разработка месторождений полезных ископаемых : Респ. межведом. науч.-техн. сб. Киев, 1991. С. 89-92.

6. Ляшко И.И., Велико-Иваненко И.М., Мистецький Г.Б. Метод мажорантных областей в теории фильтрации. Киев : Наукова думка, 1974. 200 с.

7. Едремов Э.И., Петренко В.Д., Пастухов А.И. Прогнозирование дробления горного массива взрывом. Киев : Наукова думка, 1990. 120 с. 
8. Переяславский Л.Г. Некоторые аспекты разрушения твердых тел под действием динамических нагрузок. Совершенствование и развитие буровзрывных работ на бблюсовых карьерах. Киев, 1978. С. 26-32.

9. Определение максимального размера кусков при взрывной отбойке. Горное дело: РЖ : ВИНИТИ. 1978 . № 3.

10. Альтман E.І., Большаков І.Л., Кожелупенко Ю.Д. Гідрогазодинаміка. Одеса, 2008. 350 с.

11. Веселовский В. С. и др. Самовозгорание промышленных материалов. Москва : Наука, 1964. 261 с.

12. Саранчук В.И., Баев Х.А. Теоретические основы самовозгорания угля. Москва : Недра, 1976.156 с.

13. Глузберг Е.И. Теоретические основы прогноза и профилактики шахтных пожаров. Москва : Недра, 1986.150 с.

\section{References:}

1. Dolzhenkov A.F., Negrey T.A. (2015) Analiz osnovnykh napravleniy sozdaniya bezopasnykh usloviy truda podzemnykh rabochikh ugol'nykh shakht [Study of work safety of underground workers coal mines]. Visti Donets'koho hirnychoho instytutu: Vseukrayins'kyy naukovo-tekhnichnyy zhurnal, no. 1(36)-2(37), pp. $123-129$. (in Russian)

2. Santosh Kumar Ray, Niroj Kumar Mohalik, Asfar Mobin Khan, Debashish Mishra, Nikhil Kumar Varma, Jai Krishna Pandey, Pradeep Kumar Singh (2020) CFD modeling to study the effect of particle size on dispersion in 201 explosion chamber: An overview. International Journal of Mining Science and Technology, vol. 30, issue 3, pp. 321-327. DOI: https://doi.org/10.1016/j.ijmst.2020.04.005

3. Zavyalova O.L., Kostenko V.K. (2017) Mekhanizm rozvytku vybukhiv vuhil'noho pylu v merezhi hirnychykh vyrobok shakht [Mechanism of development of coal dust explosions in the network of mine workings]. Heotekhnichna mekhanika: mizhvid. zb. nauk. prats', no. 135, pp. 125-136. (in Ukrainian)

4. Zavyalova O.L., Kostenko V.K., Krupka A.A., Duz L.E., Kraliuk M.O. (2020) Taktyka likvidatsiyi naslidkiv vybukhiv hazopylovykh sumishey $\mathrm{u}$ hirnychykh vyrobkakh vuhil'nykh shakht [Tactics of liquidation of consequences of explosions of gas-dust mixtures in mining workings of coal mines]. Naukovyy visnyk DonNTU, no. 1(2)-2(3). (in Ukrainian)

5. Levashev A.L. et al. (1991) Lokalizuyushchiye svoystva obrushennykh porod pri pozharakh v vyrabotannom prostranstve [Localizing properties of collapsed rocks in case of fires in mined-out space]. Razrabotka mestorozhdeniy poleznykh iskopayemykh: Resp. mezhvedom. nauch.-tekhn. sb. Kyiv, pp. 89-92. (in Russian)

6. Lyashko I.I., Veliko-Ivanenko I.M., Mystetskiy G.B. (1974) Metod mazhorantnykh oblastey v teorii fil'tratsii [Method of majorant domains in filtration theory]. Kyiv: Naukova Dumka, 200 p. (in Russian)

7. Efremov E.I., Petrenko V.D., Pastukhov A.I. (1990) Prognozirovaniye drobleniya gornogo massiva vzryvom [Prediction of rock mass crushing by explosion]. Kyiv: Naukova Dumka, 120 p. (in Russian)

8. Pereyaslavsky L.G. (1978) Nekotoryye aspekty razrusheniya tverdykh tel pod deystviyem dinamicheskikh nagruzok [Some aspects of the destruction of solids under the action of dynamic load]. Sovershenstvovaniye $i$ razvitiye burovzryvnykh rabot na flyusovykh kar'yerakh. Kyiv, pp. 26-32. (in Russian)

9. Opredeleniye maksimal'nogo razmera kuskov pri vzryvnoy otboyke (1978) [Determination of the maximum size of pieces during explosive breaking]. Mining: RZh: VINITI, no. 3. (in Russian)

10. Altman E.I., Bolshakov I.L., Kozhelupenko Yu.D. (2008) Hidrohazodynamika [Gidrogazodinamika]. Odesa, 350 p. (in Ukrainian)

11. Veselovsky V.S. et al. (1964) Samovozgoraniye promyshlennykh materialov [Spontaneous combustion of industrial materials]. Moskva: Nauka, 261 p. (in Russian)

12. Saranchuk V.I., Baev Kh.A. (1976) Teoreticheskiye osnovy samovozgoraniya uglya [Theoretical foundations of spontaneous combustion of coal]. Moskva: Nedra, 156 p. (in Russian)

13. Gluzberg E.I. (1986) Teoreticheskiye osnovy prognoza i profilaktiki shakhtnykh pozharov [Theoretical foundations of forecasting and prevention of mine fires]. Moskva: Nedra, 150 p. (in Russian) 